\title{
ANALISIS PENDAPATAN WARUNG BAKSO MORO SENENG
}

\author{
Yusriani Rizqy'1), Musfiati'1), Pitra Yani'), Jumadi'), Vadya Amanda'1), Abdul Haris'), Hasbiadi' ${ }^{2)}$ \\ ${ }^{1}$ Mahasiswa Program Studi Agribisnis, Universitas Sembilanbelas November Kolaka \\ ${ }^{2}$ Dosen Program Studi Agribisnis, Universitas Sembilanbelas November Kolaka \\ *Email Korespondensi : musfiatikm@gmail.com
}

\begin{abstract}
Abstrak
Bakso merupakan produk pangan yang dibuat dari daging yang dihaluskan, dicampur tepung berkarbohidrat tinggi, dibentuk bulat-bulat sebesar kelereng atau lebih besar dan dimasak dalam air panas untuk mengkomsumsinya. Bahan pokok dalam pembuatan bakso di UKM Moro Seneng adalah daging sapi, sedangkan bahan tambahan terdiri dari bahan pengisi berupa tepung, es, garam dan bumbu. Penelitian bertujuan untuk mengetahui besarnya biaya variabel, biaya tetap, dan penerimaan serta keuntungan yang didapatkan dalam UKM warung bakso Moro Seneng. Metode analisis data menggunakan perhitungan biaya, penerimaan, serta keuntungan yang dihasilkan dari proses penjualan. Pengeluaran biaya tetap perbulan rata-rata sekitar Rp 2.370.000 dengan jumlah terbesar berasal dari biaya tenaga kerja sebesar Rp 1.500.000 untuk biaya variabel sekitar Rp 24.350.000 dengan biaya terbesar berasal dari biaya bahan baku sebesar Rp 16.000.000 Penerimaan rata-rata warung bakso Moro Seneng dalam satu bulan sebesar Rp 37.500.000 dengan keuntungan satu bulan rata-rata sebesar Rp 10.780.000.
\end{abstract}

Kata kunci: Bakso, Biaya, Pendapatan,

\begin{abstract}
Meatballs are food products made from mashed meat, mixed with high carbohydrate flour, shaped into balls the size of marbles or larger and cooked in hot water to consume them. The main ingredient in making meatballs at UKM Moro Seneng is beef, while the additional ingredients consist of fillers in the form of flour, ice, salt and seasonings. This study aims to determine the amount of variable costs, fixed costs, and revenues and profits obtained in the UKM meatball stall Moro Seneng. The data analysis method uses the calculation of costs, revenues, and profits generated from the sales process. Fixed costs per month averaged around $\mathrm{Rp}$. 2,370.000 with the largest amount coming from labor costs of Rp. 1,500,000 for variable costs of around Rp. 24,350,000 with the largest cost coming from raw material costs of Rp. 16,000.000. The average revenue of Moro Seneng's meatball stalls in one month is $R p$. $37,500,000$ with an average profit of $R p .10,780,000$ for one month.
\end{abstract}

Keywords: Bakso, Cost, Income

\section{PENDAHULUAN}

Industri olahan makanan merupakan salah satu industri makanan yang saat ini berkembang pesat di Indonesia, termasuk di Kabupaten Kolaka. Aneka jenis makanan olahan yang diproduksi menggunakan varian rasa yang berbeda serta tampilan makanan yang unik, semua itu dilakukan para produsen untuk menarik minat konsumen. Adapun tahapan proses produksi makanan olahan antara lain pemilihan dan penetapan bahan baku, proses pengolahan berbagai jenis olahan makanan, proses pengujian kualitas olahan makanan, proses pengemasan, distribusi dan penjualan olahan makanan. Setiap tahapan 
proses produksi tersebut diawasi oleh para pemilik industri olahan makanan untuk menghasilkan makanan yang layak dan aman dikonsumsi (Hasbiadi, et al. 2021).

Kegiatan agroindustri adalah kegiatan industri yang mengolah hasil pertanian sebagai bahan baku atau produk akhir. Agroindustri dapat menjadi salah satu pilihan strategis dalam menghadapi masalah dalam upaya peningkatan perekonomian masyarakat. Industri dapat dikatergorikan menjadi empat meliputi industri rumah tangga, industri kecil, industri menengah, dan industri besar. Menurut kategori Biro Pusat Statistik, usaha kecil identik dengan industri kecil dan industri rumah tangga. BPS mengklasifikasikan industri berdasarkan jumlah pekerjanya, yaitu: 1) Industri mikro dengan pekerja 1-4 orang. 2) Industri kecil dengan pekerja 5-19 orang. 3) Industri menengah dengan pekerja 20-99 orang. 4) Industri besar dengan pekerja 100 orang atau lebih.

Salah satu industri mikro yang banyak dijumpai di Kabupaten Kolaka yaitu industri bakso dengan rata-rata jumlah karyawan kurang dari 4 orang dan bersifat usaha keluarga. Usaha keluarga bakso dikelola oleh para anggota keluarga sendiri dengan sistem pengolahan yang sederhana. Bakso itu sendiri merupakan produk pangan yang dibuat dari daging yang dihaluskan, dicampur tepung berkarbohidrat tinggi, dibentuk bulat-bulat sebesar kelereng atau lebih besar dan dimasak dalam air panas untuk mengkomsumsinya. Bakso daging didenifisikan sebagai produk makanan berbentuk bulatan atau lain, yang diproleh oleh campuran daging ternak (kadar daging tidak kurang dari 50\%)dengan tanpa bahan tambahan pangan yang diizinkan. Menurut jenis daging yang digunakan. Bakso yang paling populer di Indonesia adalah bakso yang dibuat dari daging sapi. Data Badan Pusat Statistik 20 persen atau sekitar 10 juta dari 48,7 juta UKM di Indonesia, diantaranya adalah pedagang usaha mi bakso, jika 60 persen saja yang aktif, berarti ada sekitar 6 juta pelaku usaha bakso di Indonesia (Yusuf, et.al. 2016).

Perubahan gaya hidup dan pola konsumsi masyarakat ini melatarbelakangi berkembangnya produsen makanan siap saji khususnya pedagang makanan salah satunya adalah pedagang bakso. Pedagang bakso merupakan salah satu jenis lapangan kerja di sektor informal, dan cukup populer khususnya diperkotaan. Bakso merupakan salah satu makanan yang sangat digemari oleh masyarakat khususnya Kabupaten Kolaka. Persaingan antar pedagang bakso sejak lama telah terjadi dan semakin berkembang. Pola pengelolaan dan pemasaran bakso yang masih sederhana dan sistem kekeluargaan menyebabkan para pedagang bakso sulit untuk membuat laporan keuangan yang baik, para pedagang juga sulit untuk menentukan biaya-biaya pada usaha bakso mereka. Lebih lanjut perhitungan pendapatan dan keuntungan pedagang bakso cenderung hanya melakukan tafsiran secara pribadi. Berdasarkan hal tersebut maka rumusan masalah dalam penelitian ini yaitu bagaimana menganalisis pendapatan warung bakso moro seneng, sedangkan tujuan penelitian yaitu untuk menganalisis pendapatan warung bakso moro seneng.

\section{METODE PENELITIAN}

Penelitian ini termasuk dalam penelitian survei dengan teknik pengambila sampel secara purposive. Penelitian ini dilakukan selama satu bulan yaitu pada bulan Maret 2021. Penelitian dilakukan di Warung Bakso Moro Seneng di kecamatan Tanggetada Kabupaten Kolaka, Sulawesi Tenggara. Metode penelitian yang digunakan adalah metode kuantitatif dengan cara mewawancarai narasumber yaitu pemilik warung bakso Moro Seneng. Alat yang digunakan dalam penelitian ini adalah alat tulis berupa buku, pulpen, serta alat perekam.

Metode analisis data dalam penelitian ini digunakan untuk mengetahui biaya yang dikeluarkan dalam setiap bulan dan juga untuk mengetahui pendapatan yang didapat dalam satu bulan serta keuntungan warung bakso Moro Seneng, oleh karena itu untuk me 
ngetahui berapa biaya yang dikeluarkan dan berapa pendapatan yang di hasilkan dari warung bakso Moro Seneng digunakanlah rumus sebagai berikut:

$$
\mathrm{TC}=\mathrm{TFC}+\mathrm{TVC}
$$

TC adalah biaya total usaha (Rp/bulan)

Perhitungan penerimaan menggunakan rumus sebagai berikut:

$$
\mathrm{TR}=\mathrm{Q} \times \mathrm{P}
$$

TR adalah penerimaan total usaha

$\mathrm{Q}$ adalah jumlah permangkok/perporsi

$\mathrm{P}$ adalah harga bakso permangkok

Perhitungan keuntungan adalah selisih antara penerimaan dengan biaya.

$$
\pi=T R-T C
$$

$\pi=$ Keuntungan $(R p /$ Bulan $)$

$\mathrm{TR}=$ Penerimaan total $(\mathrm{Rp} /$ Bulan $)$

$\mathrm{TC}=$ biaya total $(\mathrm{Rp} /$ Bulan $)$

\section{HASIL DAN PEMBAHASAN}

Usaha Warung Bakso Moro Seneng ini telah berlangsung selama 10 tahun, dalam jangka waktu tersebut usaha tersebut telah mengalami pasang surut, warung ini di kelolah oleh pasangan suami istri. Dalam warung ini mereka menyediakan bakso dan mie pangsit. Warung ini merupakan salah satu UKM yang terdapat di wilayah Tanggetada, yang menjadi pembeli mereka kebanyakan dari kalangan mahasiswa, sebagian kecil dari kalangan masyarakat sekitar.

Dalam membuat bakso bahan utama yang digunakan adalah daging (sapi, ayam, ikan) sesui selera. Sedangkan bahan tambahannya berupa garam dapur, bahan pengisi, bumbu penyedap dan es atau air es. Daging sapi digunakan karena dagingnya lebih mudah dibentuk menjadi butiran-butiran kenyal karena kandungan dan struktur proteinnya lebih kenyal dan kuat. Bakso pada mulanya hanya dikenal dan dijual didaerah pemukiman orang Cina serta dijual di restoran-restoran cina. Namun akhir-akhir ini setelah tahun 1980, bakso mulai berkembang dan mulai populer dimasyarakat selain dikota besar juga kota kecil, terutama di pelosok dan daerah wisata. Bakso dapat dijumpai di restoran mewah, hotel berbintang, warung makan sederhana, pedagang kaki lima, dan pedagang keliling, konsumen berasal dari golongan elit sampai golongan berpenghasilan rendah. Bahan-bahan dalam pembuatan bakso dijelaskan pada item-item berikut ini.

\section{Bahan - bahan Pembuatan Bakso}

Ada beberapa metode yang dikenal dalam pembuatan bakso, namun secara garis besar prinsipnya sama, yaitu meliputi tahap penghancuran daging, pembentukan adongan dan pemasakan. Penghancuran daging dapat dilakukan dengan mencacah dan mencincang (chopping) ataupun mengiling (grinding). Bahan-bahan baku bakso terdiri dari bahan utama dan bahan tambahan. Bahan utamanya adalah daging. Daging yang digunakan tergantung dari selera, yaitu daging sapi, daging ayam, daging ikan atau udang. Sedangkan bahan tambahan terdiri dari bahan pengisi berupa tepung, es, garam dan bumbu.

\section{Daging}

Daging merupakan semua jaringan hewan dan semua produk hasil pengolahan jaringan-jaringan tersebut yang sesuai untuk dimakan serta tidak menimbulkan gangguan kesehatan bagi yang memakannya. Untuk membuat bakso sapi dapat digunakan semua 
bagian dari karkas sapi,namun karena kandungan lemak dari jaringan ikat daging berbeda untuk setiap karkas maka penggunaannya disesuaikan dengan mutu yang diinginkan. Daging yang digunakan utuk membuat bakso adalah daging yang segar, lebih baik diambil sesegera mungkin setelah pemotongan tanpa mengalami proses penyimpanan sehingga dapat menghasilkan mutu yang baik. Gunawan (2013) menjelaskan daging yang baik dapat dilihat dari kualitas fisik sesuai penjelasan berikut:

1. Kualitas fisik daging sapi ideal

Terdapat lima aspek yang menentukan kualitas fisik daging sapi ideal, pertama adalah warna daging berwarna merah segar darah, kedua adalah tekstur daging tidak memiliki banyak otot, ketika disentuh dengan tangan dapat kembali kebentuk semula, beserat kecil dan halus yang meyebabkan daging empuk, ketiga adalah lemak (marbling) daging yang ideal berwarna putih dan semakin banyak lemak maka akan membantu daging menjadi tasty serta membantu proses pemasakan, keempat adalah rasa daging ideal adalah tidak anyir dan gurih, yang terakhir dari aroma daging ideal adalah berbau khas daging sapi dan tidak anyir serta tidak berbau busuk.

2. Kualitas fisik daging sapi impor

Tedapat lima aspek yang meentukan kualitas fisik daging sapi impor, pertama adalah warna daging berwarna merah segar darah, kedua adalah tekstur daging berserat kecil halus yang meyebabkan daging empuk, ketiga adalah lemak (marbling) cukup banyak pada daging dan berwarna putih, keempat adalah rasa dagingnya gurih atau tasty serta juicy daging terasa, yang teakhir adalah aroma daging adalah aroma daging yang tidak berbau busuk atau tidak anyir.

3. Kualitas fisik daging sapi lokal

Tedapat lima aspek yang meetukan kualitas fisik daging sapi lokal, pertama adalah warna daging berwarna merah segar darah, kedua adalah tekstur daging berserat besar dan banyak yang meyebabkan daging keras, ketiga adalah lemak (marbling) sedikit dan bewarna kekuning-kuningan, keempat adalah rasa dagingnya hambar, tidak tasty, dan sedikit pahit yang teakhir adalah aroma daging yang tidak berbau bususk atau anyir.

4. Perbandingan kualitas fisik antara daging sapi impor dan daging sapi lokal Persamaan kualitas fisik daging sapi impor dan lokal tedapat pada warna daging dan aroma dagingnya. Warna daging sapi yang baik adalah bewarna merah cerah dari darah segar. Perbedaan kualitas fisik daging sapi impor dan daging sapi lokal terlihat pada tekstur daging lemak atau (marbling) daging, dan rasa daging. Tekstir daging sapi impor teksturnya empuk karena serat dagingnya sedikit serta halus terlihat untuk seratnya perbandingan tebalik dengan tekstur daging sapi lokal yang teksturnya keras karena mempunyai banyak serat daging dan jelas terlihat untuk seratnya.

\section{Bahan Pengisi}

Bahan pengisi merupakan bahan bukan daging yang ditambahkan dalam pembuatan bakso. Bahan pengisi yang biasa digunakan pada pembuatan bakso adalah tepung yang mengandung karbohidrat yang tinngi misalnya tepung tapioka, dan patiaren. Tepung-tepung tersebut mempunyai kandungan protein yang rendah. Selanjutnya tujuan di tambahkan bahann pengisi seperti dalam pembuatan bakso adalah memperbaiki sifat dan mereduksi penyusutan selama pemasakan, memperbaiki sifat fisik dan cita rasa dan menurunkan biaya prodiuksi. 


\section{Garam Dan Bumbu}

Garam merupakan bahan baku yang umumya ditambahkan dalam pembuatan bakso, yang fungsinya untuk memberi rasa, mengwetkan dan melarutkan protein dalam daging. Selai garam dapur, bumbu yang biasa digunakan dalam pembuatan bakso adalah MSG (mono sodium glutamat), bawang putih dan bawang merah kadang pula ditambahkan merica atau lada yang dapat meningkatkan rasa pada bakso.

\section{Es Atau Air Es}

Fungsi air adalah untuk meningkatkan keempukan dan juice (sari minyak) daging, melarutkan protein yang mudah larut dalam air, membentuk larutan garam yang diperlukan untuk melarutkan protein larut garam, berperan sebagai fase kontinu dari emulasi daging dan menjaga temperatur produk. Penambahan air dalam bentuk es bertujuan untuk melarutkan garam dan mendistribusikannya secara merata ke seluruh bagian masa daging.

\section{Rasa}

Rasa makanan dapat dikenali dan dibedakan oleh kuncup-kuncup cecapan yang terletak papilla. Faktor yang mempengaruhi rasa yaitu senyawa kimia, suhu, kosentrasi dan interaksi pangan dengan komponen rasa yang lain. Warna pada bakso berasal dari bahan utamanya yaitu daging, bahan pengisi dan bahan pengikat serta bahan-bahan yang di tambahkan.

\section{Pembuatan Bakso}

Daging segar dipotong-potong, daging kemudian digiling dalam food processor bersama garam, STPP, dan $1 / 2$ bagian es batu. Bumbu-bumbu seperti merica dan bawang putih, tepung tapioka, dan sisa $1 / 2$ bagian es ditambahkan kedalam adonan. Adonan kembali digiling sampai tercampur rata dan menjadi legit. Adonan tersebut lalu dibentuk bulat-bulat dan dimasukan ke dalam air panas, setelah mulai mengembang bakso direbus sampai matang.

\section{Biaya Tetap}

Biaya tetap merupakan biaya yang harus terus dikeluarkan oleh perusahan tanpa dipengaruhi oleh jumlah barang atau jasa yang di hasilkan. Biaya tetap yang dikeluarkan oleh Warung Moro Seneng dapat dilihat pada tabel berikut:

Tabel 1. Rata-rata Biaya Tetap Warung Moro Seneng per bulan

\begin{tabular}{cll}
\hline No & \multicolumn{1}{c}{ Jenis Biaya } & \multicolumn{1}{c}{ Rata-rata (Rp/bulan) } \\
\hline 1 & Penyusutan peralatan & \\
& Alat makan & 50.000 \\
& Alat masak & 40.000 \\
& Tissue & 180.000 \\
& Meja dan kursi & 100.000 \\
2 & Tenaga kerja & 1.500 .000 \\
3 & Listrik dan air & 500.000 \\
\hline Total Biaya & 2.370 .000 \\
\hline
\end{tabular}

Pada Tabel 1 menunjukkan bahwa sumber biaya tetap Warung Moro Seneng berasal dari biaya tenaga kerja sebesar Rp 1.500 .000 dari total biaya tetap, biaya listrik dan air sebesar Rp 500.000 dari total biaya tetap, biaya pembelian tissue sebesar Rp $180.000,00$ dari total biaya tetap, biaya penyusutan meja dan kursi sebesar Rp 100.000 dari total biaya tetap, biaya penyusutan alat makan sebesar Rp 50.000 dari total biaya tetap, dan biaya penyusutan alat masak sebesar Rp 40.000 dari total biaya tetap. Jumlah 
keseluruhan biaya tetap yang harus dikeluarkan oleh warung tersebut adalah $\mathrm{Rp}$ 2.370.000 per bulan.

\section{Biaya Variabel}

Biaya variabel adalah biaya yang digunakan dalam usaha warung bakso Moro Seneng yang besarnya berubah-ubah secara proporsional terhadap kuantitas output yang dihasilkan. Rata-rata biaya variabel yang dikeluarkan Warung Moro Seneng dapat dilihat pada tabel berikut:

Tabel 2. Rata-rata Biaya Variabel Warung Moro Seneng Per Bulan

\begin{tabular}{lll}
\hline No & Jenis biaya variabel & Rata-rata (Rp/bulan) \\
\hline 1 & Bahan baku & 16.000 .000 \\
2 & Bahan pelengkap & 7.500 .000 \\
3 & Bahan bakar gas & 200.000 \\
4 & Pengemasan & 150.000 \\
5 & Bumbu-bumbu & 500.000 \\
\hline Total & & 24.350 .000 \\
\hline
\end{tabular}

Pada tabel 2 menunjukkan bahwa sumber biaya variabel Warung Moro Seneng per bulan berasal dari biaya bahan baku sebesar $\mathrm{Rp} 16.000 .000$ biaya bahan pelengkap sebesar Rp 7.500.000 dari total biaya variabel, biaya bumbu-bumbu sebesar Rp 500.000 dari total biaya variabel, biaya bahan bakar gas sebesar Rp 200.000 dari total biaya variabel, serta biaya pengemasan sebesar Rp 150.000 dari total biaya variabel sehingga jumlah keseluruhan biaya variabel yang harus dikeluarkan dari UKM Warung Moro Seneng adalah sebesar Rp 24.350.000.

\section{Total Biaya}

Biaya total adalah keseluruhan jumlah biaya produksi yang dikeluarkan, yaitu merupakan penjumlahan dari biaya tetap dan biaya variabel (Sudarsono, 2008). Jadi biaya total yang dikeluarkan oleh warung Moro Seneng adalah hasil dari penjumlahan seluruh biaya tetap dan biaya variabel yang dapat dilihat pada tabel berikut:

Tabel 3. Rata-rata Biaya Per Bulan Warung Moro Seneng

\begin{tabular}{lll}
\hline No & Jenis biaya & Rata-rata biaya total (Rp/bulan) \\
\hline 1 & Biaya Tetap & 2.370 .000 \\
2 & Biaya Variabel & 24.350 .000 \\
\hline Jumlah & 26.720 .000 \\
\hline
\end{tabular}

Berdasarkan tabel 3 dapat diketahui total biaya rata-rata yang dikeluarkan oleh warung Moro Seneng adalah Rp 26.720 .000 per bulan, biaya terbesar yang dikeluarkan berasal dari biaya variabel yaitu sebesar 24.350.000 dari total biaya. Hal ini disebabkan penggunaan biaya variabel lebih rutin daripada biaya tetap yaitu berupa daging sapi giling serta tepung kanji yang setiap harinya digunakan untuk produksi bakso.

\section{Penerimaan}

Penerimaan adalah sejumlah uang yang diterima dari penjualan produknya kepada pedagang atau langsung kepada konsumen. Penerimaan adalah seluruh seluruh pendapatan yang diterima tanpa melihat dari mana sumbernya, dengan besaran tidak selalu sama dalaam kurun waktu tertentu. Dalam penelitian ini penerimaan warung Moro Seneng dihitung dengan melihat jumlah perkiraan penjualan di kali harga per mangkok dalam kurun waktu satu bulan. Penerimaan dari warung Moro Seneng dapat dilihat pada tabel berikut: 
Tabel 4. Rata-rata Penjualan dan Penerimaan per Bulan Warung Moro Seneng

\begin{tabular}{lllll}
\hline No & Uraian & Harga (Rp) & Rata Penjualan(per/bulan) & Total (Rp) \\
\hline 1 & Porsi/Mangkok & 15.000 & 3.000 & 45.000 .000 \\
\hline
\end{tabular}

Tabel 4 menunjukan bahwa penerimaan rata-rata penjualan warung Moro Seneng per bulan sebanyak 2.500 mangkok dengan harga Rp 15.000 per mangkok sehingga jumlah penerimaan yang diperoleh per bulannya sebesar Rp 37.500.000.

\section{Keuntungan yang diperoleh}

Keuntungan yang diperoleh dari warung Moro Seneng merupakan selisih antara penerimaan dengan biaya total. Keuntungan ini merupakan bukti suatu uasaha itu layak dijalankan. Untuk mengetahui besarnya rata-rata keuntungan warung Moro Seneng per bulan dapat dilihat tabel dibawah ini:

Tabel 5. Rata-rata Keuntungan Per Bulan Warung Moro Seneng

\begin{tabular}{lll}
\hline No & Uraian & Rata-rata keuntungan (Rp/bulan) \\
\hline 1 & penerimaan & 37.500 .000 \\
2 & Total biaya & 26.720 .000 \\
\hline \multicolumn{2}{l}{ Keuntungan } & 10.780 .000 \\
\hline
\end{tabular}

Tabel 5 menunjukan bahawa penerimaan rata-rata perbulan Warung Moro Seneng adalah Rp 45.000.000. Dengan total biaya yang dikeluarkan per bulan rata-rata sebesar Rp 26.720 .000 sehingga rata-rata keuntungan yang diterima dari penjualan bakso di warung Moro Seneng adalah sebesar Rp 18.280.000 keuntungan yang diterima oleh bakso daging sapi di warung Moro Seneng antara lain dipengaruhi oleh perbedaan jumlah produk yang dijual, harga, dan biaya yang dikeluarkan. Semakin banyak produk yang dihasilkan dengan biaya rendah dan semakin tinggi harga poduk maka keuntungan yang diperoleh akan semakin besar. Penelitian ini sejalan dengan penelitian yang dilakukan oleh (Fathoni, et. al, 2016; Sembiring, et. al, 2010.

\section{KESIMPULAN}

Berdasarkan hasil penelitian yang telah dilakukan maka dapat diperoleh kesimpulan bahwa bakso merupakan produk pangan yang dibuat dari daging yang dihaluskan, dicampur tepung berkarbohidrat tinggi, dibentuk bulat-bulat sebesar kelereng atau lebih besar dan dimasak dalam air panas untuk mengkomsumsinya. Analisis keuntungan suatu usaha dapat dilakukan dengan menghitung jumlah biaya tetap, biaya variabel, total biaya dan penerimaan. Pengeluaran biaya tetap perbulan rata-rata sekitar Rp 2.370 .000 dengan jumlah terbesar berasal dari biaya tenaga kerja sebesar Rp 1.500.000 untuk biaya variabel sekitar Rp 24.350.000 dengan biaya terbesar berasal dari biaya bahan baku sebesar Rp 16.000.000. Penerimaan rata-rata warung bakso Moro Seneng dalam satu bulan sebesar Rp 37.500.000 dengan keuntungan satu bulan rata-rata sebesar Rp 10.780.000.

\section{UCAPAN TERIMA KASIH}

Ucapan terima kasih kami sampaikan kepada Pemilik Warung Bakso Moro Seneng yang telah memfasilitasi dalam penelitian ini serta ucpan yang sama kami sampaikan kepada Dosen Pengampuh Mata Kuliah Pengantar Agroindustri Program Studi Agribisnis, Universitas Sembilanbelas November Kolaka yang telah membimbing dan mengarahkan penelitian ini. 


\section{REFERENSI}

Fathoni, AA. Sri, M. Aulia, Q. 2016. Analisis Efisiensi Agroindustri Tahu Bakso di Kecamatan Ungaran, Kabupaten Semarang. AGRISTA. Vol.4. No. 3. HIm. 571-580.

Gunawan, L. 2013. Analisis Perbandingan Kualitas Fisik Daging Sapi Impor dan Daging Sapi Lokal. Vol 1. No. 1.

Hasbiadi, Puryantoro, La Mpia, Juniaty AB. 2021. Analisis Kinerja Pemasaran Pada Industri Olahan Makanan Di Kabupaten Kolaka. Jurnal Ekonomi Integra. Vol.11. No 2. Hlm: $186-195$.

Sembiring, Monalisa, Yanuar, Rahmat. 2010. Analisis Pendapatan Pedagang Bakso di Kota Bogor Jawa Barat. Skripsi. IPB University.

Yusuf, A. Harapin, H. Andi MT. 2016. Analisis Pendapatan Pedagang Bakso Sapidi Kabupaten Kolaka. JITRO. Vol. 3, No. 3. 